\title{
The Economy Crisis and Financial Performance
}

\author{
Mia Angelina Setiawan \\ Departement of Accounting, Faculty of Economics, Universitas Negeri Padang, Padang, Indonesia \\ $\triangle$ (e-mail) miaangelinasetiawan@gmail.com
}

\begin{abstract}
This research aims to examine the effect of firm size and insider ownership to financial performance of companies listed in the Indonesia Stock Exchange. The population is all companies listed on the Indonesia Stock Exchange with the research period of 2009 2011. Sample used is purposive sampling method amount to 66 manufacturing companies. The method of analysis used in this study is by using statistical analysis and multiple linear regression analysis. The results showed that firm size and insider ownership does not affect the financial performance as measured by the proxy return on assets (ROA). This research also shows that the financial crisis did not give negative effect to financial performance of the company.
\end{abstract}

Keywords: firm size, insider ownership, economy crisis, and financial performance

\section{Introduction}

The global financial crisis triggered by the Subprime Mortgage case in the United States in 2007, led to a domino effect on the solvency and liquidity of its financial institutions. This crisis led to America's bankruptcy of hundreds of banks, securities companies, mutual funds, pensions and insurance. The financial crisis in America also caused the crisis in Asia, such as Japan, Korea, China, Singapore, Hong Kong, Malaysia, Thailand and Indonesia. In fact, these countries have had securities from those crisis companies. Indonesia also gets the impact of Financial Crisis in America. The Composite Stock Price Index (IHSG) dropped significantly to $11 \%$ and finally trading on the Indonesia Stock Exchange was temporarily closed to (suspend) for 3 days to prevent further downturn due to negative sentiment. (www.indonesiarecovery.com).

The impact of the financial crisis was seen in the weakening of the rupiah against the US dollar reaching RP 10,000 / USD in the second week of October 2008. This is due to the outflow of foreign capital as an impact of excessive panic to the global financial crisis (http://rutacs.wordpress.com). Another impact of the financial crisis is inflation. The weakening of the Rupiah against USD causes the price of goods to rise. In fact, Indonesia still imports many needs including wheat flour and soybeans from America.

The global financial crisis has an impact on Indonesia's exports to some destination countries. During the last 5 years, Indonesia's exports to America are ranked 2nd after Japan with a range of $12 \%-15 \%$ each (http://rutacs.wordpress.com). In addition, importing countries of Indonesian products on the order of 3rd to 10th (Singapore, PRC, India, Malaysia, South Korea, Netherlands, Thailand, Taiwan) accounted for about $45 \%$ of Indonesia's total exports. From that information, it is almost certain that all of these countries are experiencing the impact of the global financial crisis that resulted in the economic slowdown in each country. Furthermore, this will lead to a decline in the ability to buy or pay for Indonesian export products.

The impact of the world financial crisis is also felt by the industrial sectors that still rely on raw materials from imported products. In fact, the crisis caused raw material prices to rise in the world market. Data from the Central Bureau of Statistics (Badan Pusat Statistik-BPS) show that the growth of the large and medium manufacturing industry sector in the fourth quarter of 2008 was minus $3.26 \%$ compared to the third quarter of the same year. While in general up to 2010 despite an increase, but growth is still below the economic growth of Indonesia, while the growth of the new manufacturing sector reached $5.41 \%$. 
The influence of the financial crisis has an effect on the declining performance of the company. Therefore, the company must strive to improve its performance that impact on shareholder welfare. Welfare can be improved through good corporate performance. Good corporate performance is also meaningful for consumers, communities, employees, and suppliers; they are the creditor and the supplier of funds. The secondary purpose of the company's establishment is for the welfare of consumers, communities, employees and creditors. The secondary goal is the driving force for the achievement of the primary objectives of good corporate performance (Atkinson, Banker, Kaplan, and Young, 1997).

Company performance shows the company's ability to benefit from assets, equity, and debt. The amount of assets is a sign of good corporate performance. Company assets become the basis for the size of a company. The size of the company can describe the financial performance of the company. In addition, company performance measures can be seen from the company's financial performance as measured by the profitability of the company.

Profitability (ROE) is one tool to measure company performance. Khaira (2011) examined the effect of capital structure, firm size, and agency cost on the performance of basic and chemical industry companies listed in Indonesia Stock Exchange in 2009. Partial test results stated that there is a significant positive effect of capital structure on agency cost and influence significantly negative company size to agency cost; while simultaneously there is no significant effect of capital structure, firm size, and agency cost on company performance.

Insider ownership or managerial ownership is a variable that can affect financial performance, as investigated by Khalil, Syed, and Zahid (2012). The results of this study conclude that the ownership structure of non-financial companies has a significant negative effect on firm performance in Pakistan. A review of various international journals, as well as the phenomenon of the financial crisis that began in 2008, hit the world market exchanges including the Indonesia Stock Exchange Market. Therefore, investigating the relationship between firm size, insider ownership, and corporate financial performance after the crisis is highly relevant to research. The reason the authors choose the manufacturing sector because the manufacturing sector is affected significantly due to the global financial crisis, based on data from the Central Bureau of Statistics (BPS) (http://www.bps.go.id) so it needs to be further examined how the company maintains the financial performance of the company.

\section{Methods}

The type of research can be classified in hypothesis testing research. This research was a type of research with problem characteristic of causality between two variables or more. The purpose of this study is to examine how the influence of one variable to other variables. The population in this study was manufacturing companies listed on Indonesian Stock Exchange (IDX) from 2009 to 2011 with purposive sampling method. As the result, the financial statements of 66 manufacturing companies from 2009, 2010, and 2011 were selected as the source of data in this study.

\section{Results and Discussion}

Table 1 Results of t-test

\begin{tabular}{|c|c|c|c|c|c|c|}
\hline \multicolumn{2}{|c|}{ Model } & \multicolumn{2}{|c|}{$\begin{array}{c}\text { Unstandardized } \\
\text { Coefficients }\end{array}$} & \multirow{2}{*}{$\begin{array}{c}\begin{array}{c}\text { Standardized } \\
\text { Coefficients }\end{array} \\
\text { Beta } \\
\end{array}$} & \multirow[t]{2}{*}{$\mathrm{T}$} & \multirow[t]{2}{*}{ Sig. } \\
\hline & & $\mathrm{B}$ & Std. Error & & & \\
\hline \multirow[t]{3}{*}{1} & (Constant) & 9.394 & 4.912 & & 1.913 & 0.057 \\
\hline & Firm Size & -0.118 & 0.749 & -0.011 & -0.158 & 0.875 \\
\hline & Insider Ownership & 0.048 & 0.079 & 0.039 & 0.613 & 0.541 \\
\hline
\end{tabular}

a. Dependent Variable: Financial Performance

Source: Data SPSS Version 16.0 
This study used data from financial statements of 66 manufacturing companies listed on the Indonesian Stock Exchange since 2009 to 2011. As such, there were 198 sample observations during the year 2009 to 2011. The significant level in this study was 5\%, meaning the risk of mistake to make a decision is $5 \%$. Test results can be seen from the Table 1 .

\section{The Effect of Corporate Size on Financial Performance}

The results of hypothesis testing for firm size with a significance value of 0.875 or greater than 0.05 , it can be concluded that the size of the company negatively affect the financial performance of manufacturing companies in IDX from 2009 to 2011. This means that the size or magnitude of a company rated from the total asset log does not guarantee the good financial performance of the company. From the phenomenon of the financial crisis that occurred, it can be concluded that the size of the company does not affect the financial performance generated by the company. So, the assumption that the company with a larger size is considered more able to face the crisis in running its business cannot be proved in the results of this study.

Based on positive accounting theory (PAT), Christie (1990) concluded that firm size is a reflection of positive accounting theory application, where Firm Size is characteristic of a company, the amount of each asset owned by the company can vary between big company and small company. Rejection of this hypothesis is likely due to the size of the total assets as the size of the company has not given confidence to investors about the company's ability to manage the investments provided, so the size of the company does not affect the performance of the company.

These findings support research conducted by Khairaamalia (2011) which report that companies' size that are from the log of total assets has no effect on the performance of basic and chemical industry companies. These findings also support BalaRamasamy, Ong and Yeung (2005) who proved that there is no significant influence between the size of the company with the financial performance of companies engaged in palm oil.

\section{The Effect of Insider Ownership to Financial Performance}

From the results of hypothesis testing with a significance value of 0.541 or greater than 0.05 , it can be concluded that the results of testing the fourth hypothesis obtained that insider ownership negatively affect financial performance at manufacturing companies in IDX from 2009 to 2011. This means that the large share ownership dominated by insider ownership or management does not guarantee the good performance of the company after the financial crisis. The rejection of this hypothesis is likely to occur because after the crisis, managerial ownership is too low that the manager's performance in managing the company is less than optimal and the manager as a minority shareholder has not been able to participate actively in making a decision in the company, thus not affecting the financial performance.

The term insider ownership is used to show the percentage of ownership by managers and institutional (Jensen and Meckling, 1976), meaning that insider ownership also describes how much shares are owned by public, insider and outsider ownership. According to agency theory, the separation between ownership and management of a company can lead to agency conflict. These agency conflicts are due to the different interests of principals and agents, the difference in interests between management and shareholders result in management cheating and unethical behavior that harms shareholders. Therefore, it is necessary to have a control mechanism that can align the difference of interest between management and stock. According to Jensen and Meckling (1976), the greater the ownership of shares by management, the stronger the tendency of management to optimize the use of resources resulting in an increase to the financial performance of the company.

These findings support research conducted by BalaRamasamy, Ong, and Yeung (2005) found that ownership structure negatively affects the financial performance of firms in Malaysia. These findings also support the research of Khalil, Syed, and Hussain (2012) which find that ownership structure negatively affects the financial performance of firms in Pakistan. The results of this study are not 
consistent with the research conducted by Lee (2008) that found the ownership structure has a positive and significant effect on the financial performance of the company in Korea.

\section{Conclusions}

Based on the results of research and discussion above, it can be concluded that, company size has significance level of 0.875 or greater than the 0.05 level of significance. This means that there is no significant influence between the size of the company on the financial performance of , anufacturing companies listing on the Indonesia Stock Exchange (BEI) after the financial crisis. So it can be concluded that the amount of total assets has not given assurance to the investors. Thus, the size of the company does not affect the performance of the company.

Insider ownership has a significance level of 0.541 or greater than the 0.05 level of significance. This means there is no significant influence between insider ownership on the financial performance of manufacturing companies listing on the Indonesia Stock Exchange (BEI) after the financial crisis. So it can be concluded that the amount of ownership dominated by insider ownership or management does not guarantee the good performance of company.

\section{References}

Atkinson, Anthony A., Banker, Rajiv D., Kaplan, Robert S., \& Young, S. Mark. (1997). Management Accounting. Second Edition. New York: Prentice Hall.

BalaRamasamy, Darryl Ong, \& Yeung, Matthew C. H. (2005). Firm size, ownership and performance in the malaysian palm oil industry. Asian Academy of Management Journal of Accounting and Finance, 1, 81-104.

Brigham \& Houston. (2001). Manajemen Keuangan. Second Book. Jakarta: Penerbit Erlangga.

Central Bureau of Statistics. (2008). Retrieved from http://www.bps.go.id/download_file/publikasi/ NAD_Indonesia_Triwulanan_2007-2010_2a.pdf

Christie, A. A. (1990). Aggregation of test statistics: An evaluation of the evidence on contracting and size hypotheses. Journal of Accounting \& Economics, 12, 15-36.

Fachrudin, Khaira Amalia. (2011). Analisis pengaruh struktur modal, ukuran perusahaan, dan agency cost terhadap kinerja perusahaan. Retrieved from http://puslit2.petra.ac.id/ejournal/index.php/ aku /article/download/18237/18105.

Green, C.J., V. Murinde \& Suppakitjarak, J. (2002). Corporate financial structure in India. Economic Research Paper No. 02/4. Centre for International, Financial and Economics Research. Department of Economics, Loughborough University, Loughborough.

Hampton, John J., (1990). Financial Decision Making: Concepts, Problems, and Cases. 4th edition. India: Prentice Hall.

Indonesian Stock Exchange. Retrieved from http://www.idx.co.id

Indonesian Stock Exchange. Indonesian Capital Market Directory. Jakarta: PT Bursa Efek Indonesia.

Jensen \& Meckling. (1976). Theory of the firm: Managerial behavior, agency cost and ownership structure. Journal of Financial Economics, 3, 305-360.

Johnsen T., \& Gjoelberg, O. (2009). Management of the Norwegian oil fund: The challenges and costs of being ethical. Scandinavian Journal of Business Research, 23(2), 1-26.

Kusumajaya, Dewa Kadek Oka. (2011). Pengaruh struktur modal dan pertumbuhan perusahaan terhadap profitabilitas dan nilai perusahaan pada perusahaan manufaktur di Bursa Efek Indonesia. Thesis. Universitas Udayana, Denpasar.

Lee, Sanghoon. (2008). Ownership Structure and Financial Performance: Evidence from Panel Data of South Korea. Retrieved from http://ssrn.com/abstract=1279919.

Modigliani, F. \& Miller, M. H. (1958). The cost of capital, corporation finance and the theory of investment. American Economic Review, 47(3), 261-297.

Murdoko, Sudarmadji, \& Sularto. (2007). Pengaruh ukuran perusahaaan, profitabilitas, leverage, dan tipe kepemilikan terhadap voluntary disclosure laporan keuangan tahunan. Procedding PESAT.

Sutrisno. (2009). Manajemen keuangan. teori, konsep, dan aplikasi: Edisi Revisi. Ekonisia. Yogyakarta. 
van Home, J.C. (2002). Financial Management Policy. International Edition. Twelfth edition. New Jersey: Prentice-Hall Inc. Englewood Cliffs.

Wahla, Khalil-Ur-Rehman, Shah, Syed Zulfiqar Ali, \& Hussain, Zahid. (2012). Impact of ownership structure on firm performance evidence from non-financial listed companies at Karachi Stock Exchange. International Research Journal of Finance and Economics, 84. ISSN 1450-2887.

Watts, R. \& Zimmerman, J. (1986). Positive Accounting Theory. Edgewood Cliffs, NJ: Prentice Hall.

http://www.indonesiarecovery.com/krisis-keuangan-global-2008/krisis-2008-terparah-sejak-the-greatdepression/7-krisis-global-2008.html

http://rutacs.wordpress.com/2008/10/30/dampak-krisis-keuangan-global-tahun-2008-terhadapekonomi-indonesia/ 